AJHSE Vol: 1 (2): 37-51, 2020

Article Ref. No.: AJHSE010205

Accepted Date: October 01, 2020

(C) 2020. CC License 4.0

www.ajhse.org

CrossMark

< click for updates
African Journal of Health, Safety and Environment

An official publication of the

Applied Environmental Bioscience and Public Health Research Group

University of Benin, Benin City, Nigeria

Open Access | Bi-annual | Peer-reviewed | International

ISSN (Online): 2695-1819 | ISSN (Print): 2695-2386

\title{
ROCK PHOSPHATE SOLUBILIZATION AND ENZYMATIC ACTIVITIES FROM INDIGENOUS BACTERIA ON CASSAVA MILL EFFLUENT CONTAMINATED SOIL
}

\author{
*Oshoma C. E., Nwodo S. O. and Obuekwe I. S. \\ "Department of Microbiology, Faculty of Life Sciences, University of Benin, P.M.B. 1154, Benin City, Nigeria. \\ *Corresponding Author Email: cyprian.oshoma@ uniben.edu Phone: +2349099727664
}

\begin{abstract}
7 processing of cassava into value-added products is associated with discharge of effluents which contain substances that have adverse effect on the environment. Remediative activity of indigenous bacteria can be stimulated by supplementing effluents with phosphorus. Rock phosphate (RP) solubilization and enzymatic activities from bacteria on the cassava mill effluents (CME) contaminated soil was investigated. Soil mixed with varying concentrations of $\operatorname{CME}(0,100,200,300,400,500$ and $600 \mathrm{ml})$ and $10 \mathrm{~g}$ of RP were analyzed on days 0 and 16. Parameters analyzed were changes in $\mathrm{pH}$, heterotrophic bacteria load, phosphate-solubilizing bacteria load, available phosphorus, acid phosphatase, cellulase and urease concentrations. The results showed that the medium containing $400 \mathrm{ml} \mathrm{CME}$ contaminated soil had the highest phosphate-solubilizing bacteria load $\left(12.60 \pm 2.08 \times 10^{6}\right.$ cfu/ml), available phosphorus (126.00 $\pm 4.08 \mathrm{mg} / \mathrm{kg})$, acid phosphatase $(9.54 \pm 0.51 \mathrm{mgN} / \mathrm{g} / \mathrm{min})$, cellulase $(15.24 \pm$ $0.81 \mathrm{mg} / \mathrm{g} / 6 \mathrm{~h})$ and urease concentration $(2.15 \pm 0.22 \mathrm{mg} / \mathrm{g} / 2 \mathrm{~h})$. The control had the lowest phosphate-solubilizing bacteria load and enzymatic activity. Biostimulation of indigenous bacteria to enhance the degradation of cassava mill effluent-contaminated soil, using rock phosphate, showed promising results. This implies that rock phosphate solubilization by indigenous bacteria in CME-contaminated soils could be important for the remediation and reclamation of contaminated lands.
\end{abstract}

Keywords: rock phosphate, cassava mill effluent, enzymatic activity, soil, solubilization

LICENSE: This article by African Journal of Health, Safety and Environment (AJHSE)is licensed and published under the Creative Commons Attribution License 4.0 International License, which permits unrestricted use, distribution, and reproduction in any medium, provided this article is duly cited.

COPYRIGHT: The Author(s) completely retain the copyright of this published article.

OPEN ACCESS: The Author(s) approves that this article remains permanently online in the open access (OA) mode.

QA: This Article is published in line with "COPE (Committee on Publication Ethics) and PIE (Publication Integrity \& Ethics)". 


\section{INTRODUCTION}

Cassava (Manihot esculenta) is one of the major food crops produced in Africa (FAO, 2004; Akponah, 2011; Muniafu et al., 2015). Nigeria is ranked amongst the leading cassava producing and exporting nations of the world. Cassava roots are important in African diet and can be processed into varieties of carbohydrate-rich staple foods for human consumption (Oti, 2002). Garri is the most popular of all the staple food products obtained from cassava and most processing plants in Nigeria produce between 7 and 10 million tonnes annually (FAO, 2004). During garri processing, the expressed juice from grated cassava pulp forms the whey, which is a major waste product. This whey is discharged into the environment as effluent referred to as cassava mill effluent (CME) (Muniafu et al., 2015).

Owing to the large amount of cassava processed at garri processing plants, which is further exacerbated by the fact that almost everyone in a locality gather to do it at centralized location, garri processing plants are associated with lots of foul odour and is an eyesore to the environment. An insidious consequence of the practices going on at these plants is the effect of the improperly disposed cassava mill effluents on the environment. In most cases, no effort is made to dispose of the effluents, they are simply allowed to wet and percolate into the ground of the processing area. When attempts are made, they are usually discharged on land or into water bodies indiscriminately (Igbinosa and Igiehon, 2015). The effluents contain large amounts of water, hydrocyanic acid, organic matter and other waste products from the sieve (Enerijiofi et al., 2017). Continuous discharge of these effluents into the environment not only generates offensive odours and damages the aesthetics of the environment, it also poses a serious health and environmental hazard (Okafor, 2008). The components of the effluents are lethal and mobile in soil, capable of altering ecology and biodiversity, causing extinction of benthic macro-invertebrates, endangering marine life, eliminating beneficial microbes in the environment and inhibiting cereal seed germination (Olorunfemi et al., 2008; Eziegbo et al., 2014; Igbinosa and Igiehon, 2015). Nonetheless, cassava mill effluents also contain many nutrients, capable of supporting the growth of microbes that can tolerate the toxic components. Therefore, the discharge of effluents onto lands or into water bodies, selectively lead to the proliferation of certain microbes. The rapid growth of these microbes can cause oxygen depletion in water bodies leading to death of fish and other aquatic organisms (Oboh et al., 2002; Horsfall et al., 2006).

The process of utilizing microorganisms to clean up contaminated environment is termed bioremediation (Eziegbo et al., 2014; Divya et al., 2015). One of the strategies to enhance successful bioremediation processes is the supply of nutrients to improve the metabolic activity of the microbes used known as biostimulation (Erenee et al., 2017). Phosphorus is one of the supplementing nutrients that plays a significant role in physiological and biochemical growth of microorganisms (Kadiri et al., 2013). Microbes require phosphorous for energy and nucleic acid synthesis. The use of rock phosphate has been documented to be successful and increases the rate of microbial degradation of contaminated environment (Sharma et al., 2013; Ovasogie et al., 2015; Agyarko et al., 2017).

The growth of phosphate-solubilizing bacteria (PSB) and fungi (PSF) for the treatment of polluted soil depends on cultural activities and soil properties, such as physico-chemical properties, organic matter and soil phosphorus content (Sharma et al., 2013). Cassava mill effluent-polluted soil is one of such soils with characteristic physical and chemical properties, organic matter and phosphorus content. The application of rock phosphate to aid PSB and PSF in the remediation of cassava mill effluent-polluted soil is a field of interest, which demands plausible 
attention as increasing the phosphate quantity of polluted soil may result in quicker reclamation of polluted soil in Nigeria, thus, enhancing soil fertility (Alori et al., 2017). Hence, biostimulation through amendment with growthlimiting factors, such as phosphorus, can enhance microbial degradation on contaminated sites (Abbasi et al., 2015; Utobo and Tewari, 2015). Therefore, this study focused on the use of phosphate rocks as biostimulant for the microbial bioremediation of cassava mill effluents. The aim was to investigate rock phosphate solubilization and enzymatic profile of the indigenous bacteria on cassava mill effluent-contaminated soil.

\section{METHODOLOGY}

\section{SAMPLE COLLECTION}

Cassava mill effluents were collected from cassava processing mill site at Isihor, Benin City, Edo State, Nigeria. Sterile 10-L plastic containers were used to collect samples in triplicates and taken to the laboratory for analyses. Soil samples were collected from fallow farmland using hand-held auger into air-tight nylon bags and were transported immediately to the laboratory for analyses. The soil samples were air-dried for a period of one week in a clean wellventilated laboratory, homogenized, passed through a $2-\mathrm{mm}$ stainless sieve, and stored in labelled plastic cans until analyses. Rock phosphate was obtained from a commercial fertilizer outlet in Benin City.

\section{PREPARATION OF BIOREMEDIATION MEDIUM}

Dried soil samples $(2 \mathrm{~kg}$ ) were weighed into seven plastic containers and spiked with $10 \mathrm{~g}$ of powdered rock phosphate (RP). The spiked soil was mixed with varying amounts of cassava mill effluent $(0,100,200,300,400,500$ and 600 $\mathrm{mL}$ ), transferred into respective plastic containers. control soil plastic container composed of only $2 \mathrm{~kg}$ of soil without $\mathrm{RP}$ and CME. Each set-up was allowed to undergo biodegradation for 16 days at $28 \pm 2{ }^{\circ} \mathrm{C}$ after which samples were drawn for analyses. The parameters analyzed were bacteria load, phosphate-solubilizing bacteria (PSB) load, changes in $\mathrm{pH}$, available phosphorus, as well as concentrations of acid phosphatase, cellulase and urease.

\section{ENUMERATION OF TOTAL HETEROTROPHIC BACTERIA AND PHOSPHATE-SOLUBILIZING BACTERIA}

Ten-fold serial dilution of the soil samples was prepared. Triplicate soil samples were suspended in sterile saline solution and shaken for $1 \mathrm{~h}$. For heterotrophic bacteria, an aliquot of $0.1 \mathrm{ml}$ was transferred, using spread plated method, onto plates containing Nutrient Agar. All the plates were incubated at $28 \pm 2{ }^{\circ} \mathrm{C}$ for $24 \mathrm{~h}$ after which bacteria counts were estimated from the colonial growth. For phosphate-solubilizing bacteria count, an aliquot of serially diluted soil samples was transferred, using spread plated method, onto plates containing standard National Botanical Research Institute's phosphate (NBRIP) agar medium. The NBRIP medium composed of glucose (10 g), $\mathrm{MgCl}_{2} .6 \mathrm{H}_{2} \mathrm{O}$ $5 \mathrm{~g}, \mathrm{MgSO}_{4} .7 \mathrm{H}_{2} \mathrm{O}(0.25 \mathrm{~g}), \mathrm{KCl}(0.2 \mathrm{~g})$ and $\left(\mathrm{NH}_{4}\right)_{2} \mathrm{SO}_{4}(0.1 \mathrm{~g})$, dissolved in $1 \mathrm{~L}$ distilled water and supplemented with $5 \mathrm{~g}$ tribasic calcium phosphate (TCP). The plates were incubated at $28 \pm 2{ }^{\circ} \mathrm{C}$ for 3 days. Colonies with clear zones around them were considered as phosphate-solubilizing bacteria species and counted (Nautiyal et al., 2000).

Discrete colonies of bacterial isolates were purified by sub-culturing into freshly prepared nutrient plates for bacteria. Pure cultures of bacterial isolates were characterized and identified based on their cultural, morphological and 
biochemical characteristics using the scheme in Bergey's manual of determinative bacteriology (Holt et al., 1994; Cheesbrough, 2006)

\section{DETERMINATION OF pH}

Changes in $\mathrm{pH}$ were monitored using a pH meter model 314P.

\section{DETERMINATION OF AVAILABLE PHOSPHORUS}

Available phosphorus of the soil samples was determined according to the method described by Watanabe and Olsen (1965). The concentration of phosphorus was determined using a spectrophotometer (Unico S1205 \& S2100 + series) at a wavelength of $712 \mathrm{~nm}$.

\section{DETERMINATION OF ACID PHOSPHATASE CONCENTRATION}

One gram of soil sample was homogenized in $10 \mathrm{~mL}$ of ice-cold $50 \mathrm{mM}$ citrate buffer $(\mathrm{pH}$ 6.5) using a pre-chilled mortar and pestle. The assay was based on the colorimetric estimation of p-nitrophenol releases by phosphatase activity according to the method of Alef and Nannipieri (1995).

\section{DETERMINATION OF CELLULASE CONCENTRATION}

Cellulase concentration was determined based on released reducing sugars after the incubation of carboxy-methylcellulose salt solution (CMC) with soil samples for $24 \mathrm{~h}$ at $50{ }^{\circ} \mathrm{C}$ (Alef and Nannipieri, 1995).

\section{DETERMINATION OF UREASE CONCENTRATION}

Urease concentration was determined as described by Hoffmann and Teicher (1961). The enzyme assay was based on measuring the ammonium released using a spectrophotometer (Unico S1205 \& S2100 + series) at $578 \mathrm{~nm}$. Three replicates of each sample were tested, and a control sample without urea was prepared.

\section{DATA ANALYSIS}

All experiments were carried out in triplicate. Descriptive statistics and analysis of variance were done using Statistical Package for the Social Sciences (SPSS) version 20.

\section{RESULTS}

Varying amounts of cassava mill effluent was used in the study to determine the optimum amount of cassava mill effluent that can be tolerated by the microbes in the presence of rock phosphate for efficient biodegradation process. Heterotrophic bacteria load and phosphate-solubilizing bacteria at the beginning and day 16 of solubilization of $10 \mathrm{~g}$ of RP with varying concentrations of CME in the soil is shown in Table 1. In all setups, microbial counts were higher at day 16. The highest bacterial load of $28.30 \pm 1.15 \times 10^{6} \mathrm{cfu} / \mathrm{ml}$ at day 16 was recorded for the soil sample mixed with $600 \mathrm{ml}$ of cassava mill effluent. The control had the least count of $5.23 \pm 0.15 \times 10^{6} \mathrm{cfu} / \mathrm{ml}$ at day 16 . The highest 
phosphate-solubilizing bacteria (PSB) count $\left(12.60 \pm 2.08 \times 10^{6} \mathrm{cfu} / \mathrm{ml}\right)$ was observed in the soil mixed with $400 \mathrm{ml}$ cassava mill effluent at day 16 . The least count of $0.97 \pm 0.30 \times 10^{6} \mathrm{cfu} / \mathrm{ml}$ was from the control.

Table 2 showed the identified bacterial isolates from CME contaminated soil. The identified bacterial isolates were Bacillus subtilis, Escherichia coli, Salmonella enterica, Staphylococcus aureus, Micrococcus luteus, Proteus mirabilis and Pseudomonas fluorescens.

Changes in $\mathrm{pH}$ and available phosphorus at the beginning and at 16 days of solubilization of $10 \mathrm{~g}$ RP with varying concentration of CME in the soil is presented in Table 3. The $\mathrm{pH}$ values were lower at 16 days compared to the values at the start of the setups in most experimental setups except for soils mixed with 300 or $600 \mathrm{CME}$. The highest $\mathrm{pH}$ at day 16 of solubilization was recorded for the setup containing $500 \mathrm{ml}$ of CME (5.75 \pm 0.03$)$ while the least was for soil with $200 \mathrm{ml} \mathrm{CME}$. The levels of available phosphorus were found to be dependent on the concentration of CME in the soil. Available phosphorus concentration in the contaminated soils after 16 days (Table 3) was highest in soils with the $400 \mathrm{ml}$ of CME while the least was from the control with values of $126.00 \pm 4.08$ and $9.67 \pm 2.93 \mathrm{mg} / \mathrm{kg}$, respectively.

Acid phosphatase activity with varied CME in the soil medium is shown in Figure 1. Amongst the varied CME contaminated soil, that with $400 \mathrm{ml} \mathrm{CME} \mathrm{gave} \mathrm{the} \mathrm{highest} \mathrm{acid} \mathrm{phosphatase} \mathrm{activity} \mathrm{of} 9.54 \pm 0.51 \mathrm{mgN} / \mathrm{g} / \mathrm{min}$. The least acid phosphatase activity of $1.05 \pm 0.41 \mathrm{mgN} / \mathrm{g} / \mathrm{min}$ was from control soil.

Urease activity during solubilization of $10 \mathrm{~g}$ of RP with varying concentrations of $\mathrm{CME}$ in the contaminated soil is shown in Figure 2. Soil with $400 \mathrm{ml}$ of CME had the highest urease activity of $2.15 \pm 0.22 \mathrm{mg} / \mathrm{g} / 2 \mathrm{~h}$ at day 16 of degradation while the control had the least urease activity of $0.06 \pm 0.00 \mathrm{mg} / \mathrm{g} / 2 \mathrm{~h}$.

Figure 3 shows cellulase activity with varied CME in the soil medium in the presence of RP. Here too, soil with $400 \mathrm{ml} \mathrm{CME}$ had the highest cellulase activity of $15.24 \pm 0.81 \mathrm{mg} / \mathrm{g} / 6 \mathrm{~h}$ and the control had least cellulase activity of $1.51 \pm 0.02 \mathrm{mg} / \mathrm{g} / 6 \mathrm{~h}$. 
Table 1: Bacterial load and phosphate-solubilizing bacteria at days 0 and 16 of solubilization of $10 \mathrm{~g}$ of RP with varying concentrations of CME in the contaminated soil. Values are means \pm S.D. of three replicates

\begin{tabular}{|c|c|c|c|c|}
\hline \multirow{2}{*}{ Parameter } & \multicolumn{2}{|c|}{ Heterotrophic Bacteria $\left(x 1^{6} \mathrm{cfu} / \mathrm{ml}\right)$} & \multicolumn{2}{|c|}{$\begin{array}{l}\text { Phosphate-solubilizing Bacteria (x } \\
\left.\qquad 10^{6} \mathrm{cfu} / \mathrm{ml}\right)\end{array}$} \\
\hline & Day 0 & Day16 & Day 0 & Day 16 \\
\hline RPCME0 & $3.73 \pm 0.17$ & $7.50 \pm 0.28$ & $0.67 \pm 0.15$ & $1.50 \pm 0.21$ \\
\hline RPCME100 & $4.73 \pm 0.88$ & $9.93 \pm 1.45$ & $1.10 \pm 0.06$ & $4.30 \pm 0.58$ \\
\hline RPCME200 & $6.07 \pm 0.88$ & $12.47 \pm 3.53$ & $1.33 \pm 0.12$ & $5.43 \pm 0.12$ \\
\hline RPCME300 & $7.27 \pm 0.88$ & $15.07 \pm 0.88$ & $1.93 \pm 0.20$ & $6.67 \pm 0.23$ \\
\hline RPCME400 & $8.90 \pm 1.53$ & $19.40 \pm 1.73$ & $2.40 \pm 0.15$ & $12.60 \pm 2.08$ \\
\hline RPCME500 & $12.47 \pm 0.88$ & $25.67 \pm 2.18$ & $3.03 \pm 0.88$ & $12.07 \pm 0.88$ \\
\hline RPCME600 & $13.50 \pm 1.00$ & $28.30 \pm 1.15$ & $3.23 \pm 0.33$ & $11.33 \pm 1.86$ \\
\hline Control & $2.57 \pm 0.17$ & $5.23 \pm 0.15$ & $0.23 \pm 0.07$ & $0.97 \pm 0.30$ \\
\hline
\end{tabular}

Table 2: Identification of bacterial isolated from CME contaminated soil

\begin{tabular}{ll}
\hline Isolates & Identity \\
\hline A & Proteus mirabilis \\
B & Escherichia coli \\
C & Pseudomonas fluorescens \\
D & Micrococcus luteus \\
E & Staphyloccus epidermidis \\
F & Salmonella enterica \\
G & Bacillus subtilis \\
\hline
\end{tabular}


Table 3: Changes in $\mathrm{pH}$ and available phosphorus at days 0 and 16 of solubilization of $10 \mathrm{~g}$ RP with varying concentration of CME in the soil. Values are means \pm S.D. of three replicates

\begin{tabular}{llcccc}
\hline & \multicolumn{2}{c}{ Changes in $\mathrm{pH}$} & & \multicolumn{2}{c}{ Available Phosphorus $(\mathrm{mg} / \mathrm{kg})$} \\
\cline { 2 - 3 } \cline { 5 - 6 } Parameter & Day 0 & Day 16 & & Day 0 & Day 16 \\
\hline RPCME0 & $4.42 \pm 0.02$ & $4.33 \pm 0.01$ & & $6.67 \pm 1.45$ & $15.00 \pm 2.08$ \\
RPCME100 & $4.39 \pm 0.02$ & $4.17 \pm 0.03$ & & $11.00 \pm 0.58$ & $43.00 \pm 0.58$ \\
RPCME200 & $5.25 \pm 0.02$ & $4.90 \pm 0.03$ & & $13.33 \pm 1.20$ & $54.33 \pm 1.20$ \\
RPCME300 & $5.09 \pm 0.30$ & $5.11 \pm 0.02$ & & $19.33 \pm 2.00$ & $66.67 \pm 2.03$ \\
RPCME400 & $6.02 \pm 0.01$ & $5.14 \pm 0.02$ & & $24.00 \pm 1.15$ & $126.00 \pm 4.08$ \\
RPCME500 & $6.30 \pm 0.15$ & $5.75 \pm 0.03$ & & $30.33 \pm 0.88$ & $120.67 \pm 0.88$ \\
RPCME600 & $6.29 \pm 0.03$ & $5.71 \pm 0.03$ & & $32.33 \pm 0.33$ & $113.33 \pm 1.86$ \\
Control & $4.37 \pm 0.12$ & $4.53 \pm 0.01$ & & $2.33 \pm 0.67$ & $9.67 \pm 2.93$ \\
\hline
\end{tabular}

RP =Rock Phosphate, CME = Cassava Mill Effluent

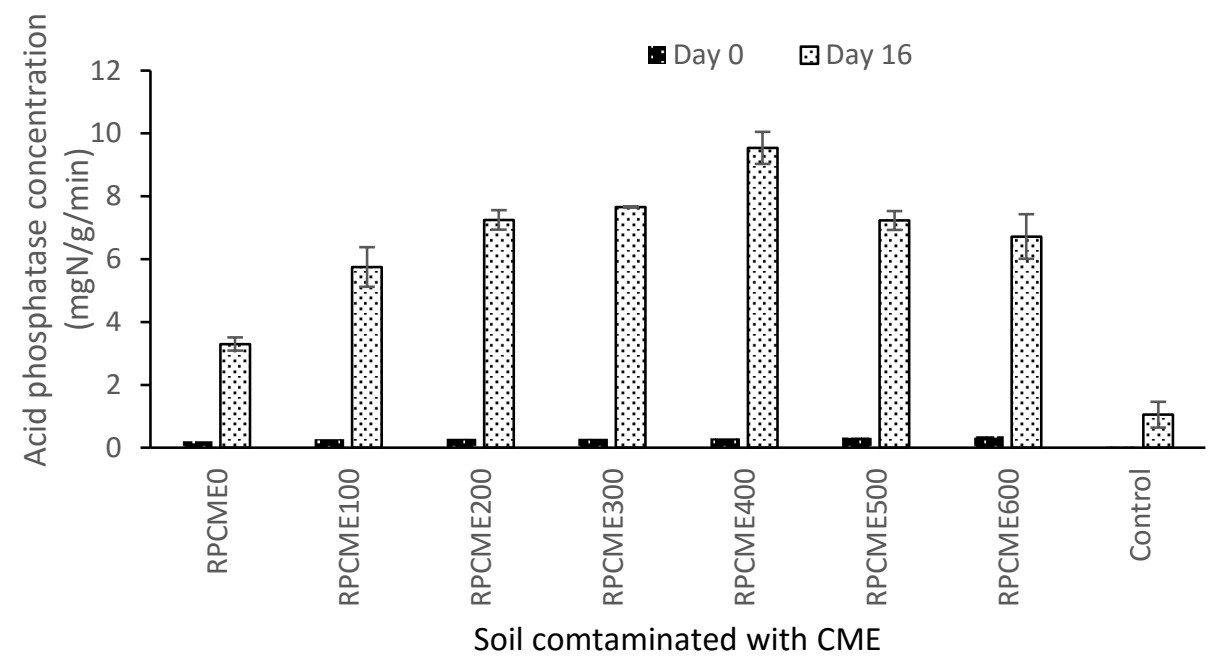

Figure 1: Acid phosphatase concentration in soils containing $10 \mathrm{~g}$ of RP mixed with varying concentration of CME. Values are the mean of three replicates and error bars represent standard deviation 


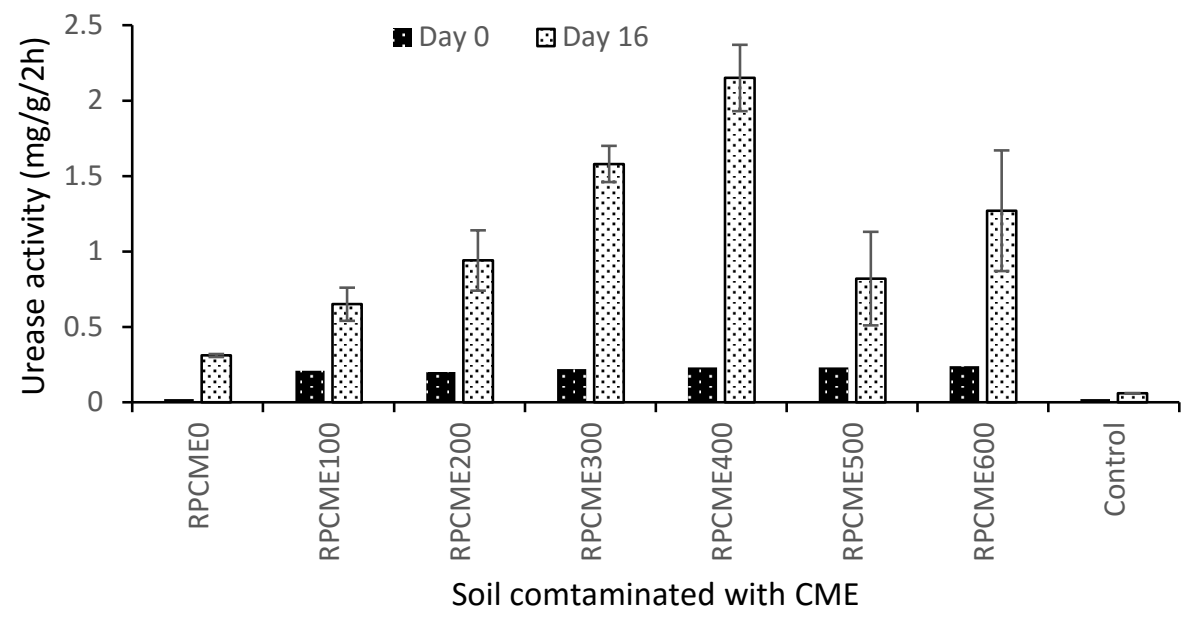

Figure 2: Urease concentration in soils containing $10 \mathrm{~g}$ of RP mixed with varying concentration of CME. Values are the mean of three replicates and error bars represent standard deviation

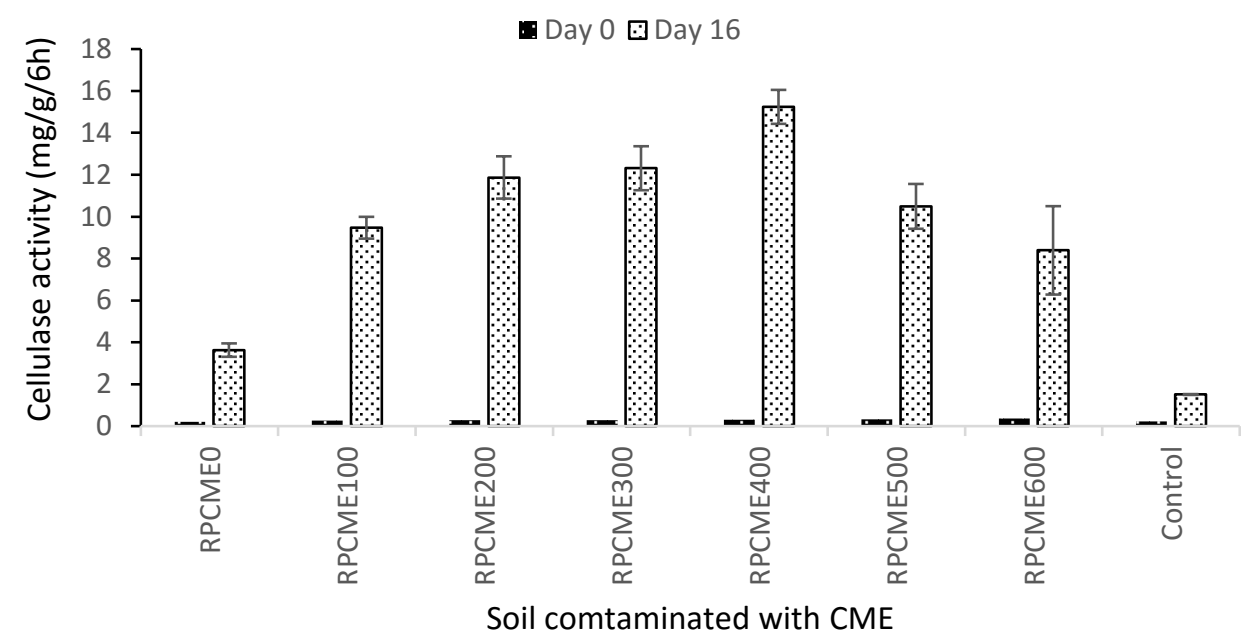

Figure 3: Cellulase concentration in soils containing 10g of RP mixed with varying concentration of CME. Values are the mean of three replicates and error bars represent standard deviation

\section{DISCUSSION}

The impact of CME supplementation with phosphate rock resulted in increased bacterial load when compared with the soil without CME and RP in this study. Increase in bacterial load when compared to soil without CME and RP could be attributed to increased concentration of growth limiting nutrients lacking in the control. The increase in heterotrophic bacterial growth observed was directly proportional to the concentration of cassava mill effluent in the setup, while the control had very minimal growth. The highest growth was in soil mixed with $400 \mathrm{ml} \mathrm{CME}$. The results obtained, support the assertion that the effluents though toxic are rich in nutrients and are capable of supporting the 
growth of microbes tolerant to or capable of degrading its toxic components (Oshoma et al., 2019). The high level of microbial growth as seen in the treatments but not in the control could also be due to the rock phosphate added to the treatments.

Phosphate-solubilizing microorganisms are made up of various groups and species of microorganisms, which not only assimilate phosphorus from insoluble forms of phosphates, but also cause a large portion of soluble phosphates to be released in quantities in excess of their requirements (Sagervanshi et al., 2012). They possess the ability to convert the insoluble phosphate into soluble forms by secreting organic acids resulting in improved phosphate availability to plants. Sagervanshi et al. (2012) noted that seed or soil inoculated with some strains of microbes improved the solubilization of fixed soil phosphorus. The increased number of these phosphate-solubilizing bacteria as observed in this study, improved the physicochemical, biochemical and biological properties of rockphosphate amended soil (Oshoma et al., 2019).

Also, the growth of bacterial in the cassava mill contaminated environment could imply that these microbes are utilizing the cassava mill effluents as a medium for growth; thus, implicating the bacteria adapting and subsequently degrading the contaminant (Oviasogie et al., 2014). Enerijiofi et al. (2017) reported that cassava mill effluents are rich in organic matters that can be metabolized by microbial enzymes. They also posited that the cassava mill effluents also serve as primary carbon and energy source for the microorganisms. However, Ajuzie et al., (2015) have reported that although microbes are found to live in cassava mill effluent-polluted environments, this is not a direct indication that the effluent serves as the primary carbon and energy sources utilized by the microbe but could be a secondary carbon and energy source.

Phosphorus is an essential macronutrient required by microorganisms for growth and metabolic activities (Cao et al., 2002). The major source of phosphorus is phosphate rock (PR), a phosphate-bearing mineral which is a finite and non-renewable natural resource. Phosphate-solubilizing fungi (PSF) possess the capability to change the insoluble form of phosphorus into soluble one, resulting in the availability of phosphorus for optimum growth and improvement of environments (Vyas and Dave, 2010). The results obtained in this study have shown the capacity of certain microbes to adapt to the toxic nature of cassava mill effluents in order to metabolize and probably degrade it. The bacteria in the rock phosphate amended in the CME-contaminated soils increased in population. The counts were higher in CME-contaminated soil with a concentration of $400 \mathrm{ml}$ than other contaminated soils. Similar investigation attributed the proliferation to bacteria growth, which utilized the organic matter from the CME (Enerijiofi et al., 2017). The bacterial population of CME-contaminated soils revealed that the added RP elevated the population. Phosphorus is a necessary nutrient for bioremediation of polluted environments which is required as phospholipids for the synthesis of nucleic acids, cell membranes and energy generation (Bashir et al., 2018).

Phosphate solubilization and available phosphorus was higher in soils amended with rock phosphate and CME compared to unamended soil where the increase was just slight. The difference could be attributed to the fact that, in unamended soil, there was no much residual phosphorus in the medium for the bacterial cultures to utilize, resulting in low concentration of the phosphorus in the medium. This agrees with findings of Khan et al. (2014) who reported that during mineralization of rock phosphate, living organisms have the ability to transform the inorganic forms of phosphorus to organic phosphate which are then incorporated into their living cells. Phosphate solubilization 
rate is greatly influence by the ability of microorganisms to produce organic acids from the carbon source substrate (Agyarko et al., 2017), such as acetic, lactic and citric acid, thus, dropping the $\mathrm{pH}$ of the medium. These organic acids solubilize rock phosphate using acidification, chelation and exchange reactions (Arumanayagam and Arunmani, 2014). Therefore, the rock phosphate amendment could have to have provided additional phosphorus source during solubilization and utilization, making net available phosphorus to be higher in the treated soil media compared to the unamended medium (Gupta et al., 2007; Sharma et al., 2013; Gomes et al., 2014).

The $\mathrm{pH}$ of the CME-contaminated soil amended with rock phosphate reduced while that of the control increased. The $\mathrm{pH}$ of cassava mill effluents has been found to be acidic, the probable reason for the further decrease in the $\mathrm{pH}$ of the setups could be due to the production of organic acids by the microbes involved in the phosphate solubulization activity within the CME contaminated soils amended with rock phosphate. This observation supports the high bacterial count recorded in this study with the CME contaminated soil. Oshoma et al. (2017) have suggested that the nature of contaminants and density of microbial diversity can alter the microbial activity in soil, especially the $\mathrm{pH}$ and enzymatic activities, thereby resulting in observable changes in the compositional structure and nature of the soil. This agrees with the work of Sane and Mehta (2015), who have documented that phosphorus-solubilizing microorganisms are reported to dissolve insoluble phosphates by the production of inorganic or organic acids there by decreasing the $\mathrm{pH}$ of the environment.

The rock phosphate-amended soils had higher amounts of available phosphorous compared to the control that had no rock phosphate added. It was observed that the setup with $400 \mathrm{ml}$ cassava mill effluent had the highest amount of available phosphorous $(\mathrm{mg} / \mathrm{kg})$, which is good to the environment since phosphorus is required for microbial growth and development (Bashir et al., 2018).

Microbial activities, conditions and biological interactions in the soil are good indicators for monitoring enzymatic activities of polluted soil (Igbinosa, 2015). Soil enzymes are important for catalyzing innumerable reactions necessary for life processes of microbes in soils, decomposition of organic residues, cycling of nutrients and formation of organic matter and soil structure (Mohamed et al., 2012). They help in the biochemical transformations of pollutants in the soil and also function as a measure of soil fertility (Acosta-Martínez and Tabatabai, 2000). Enzyme activities in soil have also been related to active soil biomass and may be used as a sensitive indicator of soil quality (Ciarkowska and Solek-Podwika, 2012). Enzymatic activities can reflect the biological state in the soil. The acid phosphatase which is the enzyme responsible for the breakdown of rock phosphate (Aseri et al., 2009), had its highest activity recorded in the bioremediation setup with $400 \mathrm{ml}$ cassava mill effluent. This reason for this could be that $400 \mathrm{ml}$ cassava mill effluent was the optimum tolerable concentration of the pollutant. It could as well be the maximum concentration of the effluent that the microbes could endure while showing peak remediation activity. Furthermore, the production of phosphatase suggested a potential application as biofertilizer in the CME contaminated soil (Jena and Rath, 2014). Soil urease activity is also closely related with soil salinity in saline soils and can be used as an index to determine the level of soil degeneration and reclamation and availability of nitrogen (Jena and Rath, 2014). Ureases are one of the essential enzymes in the soil and used as an indicator of overall soil microbial activity. The urease activity revealed an increase from the rock phosphate amended soil than the control. The $400 \mathrm{ml}$ cassava mill effluent contaminated 
soil had the highest urease activity. This implies that amendment of contaminated soil with rock phosphate will aid fertility of such contaminated soil (Maharana and Patel, 2013).

As observed in this study, soil with $400 \mathrm{ml}$ cassava mill effluent had the highest cellulase activity. The presence of utilizable polysaccharides in cassava mill effluents could be the reason why it supports microbial proliferation. Microbes growing on lignocellulosic materials have the ability to breakdown the polymer units of the polysaccharides into simple sugars (Adetunji et al., 2017). The utilization of polysaccharides, such as cellulose in cassava mill effluents involves production of the enzyme cellulase. The amount of cellulase produced by indigenous microorganisms in an environment is determined by the availability of raw material or substrate available (Maharana and Patel, 2013). The proliferation of microbes within the effluents in addition to the presence of these sugars and rock phosphate further enhanced growth and metabolism. This study has shown that indigenous bacteria have the capability of enhancing the bioremediation of CME-contaminated soils in the presence of rock phosphate.

\section{CONCLUSION}

The study revealed that rock phosphate could supply phosphorous, as a limiting nutrient whose deficit could influence negatively on microbial growth and metabolisms. The solubilized rock phosphate is subsequently made available and acts as a good biostimulant for supporting the growth of bacteria in cassava mill effluent contaminated soil. Also, the amended soil with RP enhanced enzymatic activity, hence, improvement of soil fertility. Subsequently, bioremediation and land reclamation of CME-polluted soil can be enhanced.

\section{CONFLICT OF INTEREST}

The authors declare no conflict of interest. 


\section{REFERENCES}

Abbasi, M. K., Musa, N. and M. Manzoor, M. (2015). Mineralization of soluble P fertilizers and insoluble rock phosphate in response to phosphate-solubilizing bacteria and poultry manure and their effect on the growth and P utilization efficiency of chilli (Capsicum annuum L.) Biogeosciences, 12: 4607-4619.

Acosta-Martínez, V. and Tabatabai, M.A. (2000). Enzyme activities in a limed agricultural soil. Biology and Fertility Soils 31:85-91.

Adetunji, A.T., Lewu, F.B., Mulidzi, R. and Ncube, B. (2017). The biological activities of $\beta$-glucosidase, phosphatase and urease as soil quality indicators: a review. Journal of Soil Science and Plant Nutrition 17(3): 794-807.

Alef, K. and Nannipieri, P. (1995). Enzyme activities. In: Alef, K. and Nannipieri, P., Eds., Methods in Soil Microbiology and Biochemistry, Academic Press Inc., San Diego. 311-373.

Agyarko K., Frimpong, K.A. and Abunyewa, A.A. (2017). Phosphorus release dynamics under phosphate rock and ammonium sulphate in soil amendment. Eurasian Journal of Soil Science 6(4): 312 - 318.

Ajuzie, C. U., Atuanya, E. I. and Enerijiofi, K. E. (2015). Biodegradation potentials of microorganisms isolated from Eleme petrochemical industrial effluent. Nigerian Society of Experimental Biology Journal 5(4):128-135.

Akponah, E. (2011). Production of Ethanol from Cassava (Mannihot esculenta) waste water using Saccharomyces cerevisiae and Escherichia coli. Nigerian of Journal of Microbiology, 25: 2369 - 2378

Alori, E.T., Glick, B.R. and Babalola, O.O. (2017). Microbial Phosphorus Solubilization and Its Potential for use in sustainable Agriculture. Frontiers in Microbiology 8: 971.

Arumanayagam, S. and Arunmani, M. (2014). Rock phosphate solubilization by ectomycorrhizal fungus Laccaria fraternal and its associated mycorrhizal helper bacterial strains African Journal of Biotechnology 13(25): $2524-2530$.

Aseri, G. K., Jain, N. and Tarafdar, J. C. (2009). Hydrolysis of organic phosphate forms by phosphatases and phytase producing fungi of arid and semi-arid soils of India. American-Eurasian Journal of Agriculture and Environmental Science 5:564-570.

Bashir, Z., Zargar, M.Y., Baba, Z.A., Mohiddin, F.A., Peer, F.A., Mir S.A. and Najar G.R. (2018). Isolation and characterization of phosphorus solubilizing bacteria (PSB) from rhizospheric soils of apple (Malus Domestica). Journal of Pharmacognosy and Phytochemistry 7(2): 2997-3000

Cao, R. X., Ma, L. Q., Chen, M., Singh, S. and Harris, W. (2002). Impacts of phosphate amendments on lead biogeochemistry at a contaminated site. Environmental Science and Technology 36:5296-5304.

Cheesebrough, M. (2006). District Laboratory Practice in Tropical Countries. Part II, London, Cambridge University Press. pp 58-100.

Ciarkowska, K. and Katarzyna Sołek-Podwika, K. (2012). Influence of Intensive Vegetable Cultivation in Ground and under Foil Tunnels on the Enzymatic Activity of the Soil. Polish Journal Environmental Studies 21(6): 1571-1575 
Divya, M., Aanand, S., Srinivasan, A. and Ahilan, B. (2015). Bioremediation - An eco-friendly tool for effluent treatment: A Review. International Journal of Applied Research 1(12): 530-537.

Enerijiofi, K.E., Ekhaise, F.O. and Ekomabasi, I.E. (2017). Biodegradation Potentials of Cassava Mill Effluent (CME) by Indigenous Microorganisms. Journal of Applied Science and Environment Management 21(6):1029-1034

Erenee, B.F., Kinika, R.W., Uzor, C.A., Okah, A.E and Solomon, L. (2017). A Conspectus Review Efficacy of Locally Sourced Organic Biostimulants on Enhanced Biodegradation of Hydrocarbon-Contaminated Soil Report and Opinion 9(4):62 - 69.

Ezeigbo, O.R.., Ike-Amadi, C.A., Okeke, U.P. and Ekaiko, M.U. (2014). The effect of cassava mill effluent on soil microorganisms in Aba, Nigeria. International Journal of Current Research in Biological Science and Plant Biology 1(4):21 - 26.

FAO (2004). The global cassava development strategy. Published by Food and Agricultural Organization.

Gomes, E. A., De Cássia Silva, U., Marriel, I. E., De Oliveira, C. A. and De Paula Lana, U. G. (2014). Rock Phosphate Solubilizing Microorganisms Isolated from Maize Rhizosphere Soil. Revista Brasileira de Milho e Sorgo 13(1): 69-81.

Gupta, N., Sabat, J., Parida, R. and Kerkatta, D. (2007). Solubilization of tricalcium phosphate and rock phosphate by microbes isolated from chromite, iron and manganese mines. Acta Botanica Croatica 66:197-204. 2007.

Hoffmann, G.G. and Teicher, K. (1961). A colorimetric method for the determination of urease activity in soils, Zeitschrift für Pfl anzenernahrung und Bodenkunde Journal of Plant Nutrition and Soil Science, 91: 55-63.

Holt, J.G., Krieg, N.R., Sneath, P.H.A., Staley, J.T. and Williams, S.T. (1994). Bergey's Manual of Determinative Bacteriology. 9th edition. Lippincott Williams and Wilkins Philadelphia, Baltimore, Tokyo. 787 pp.

Horsfall, M., Abia, A.A. and Spiff, A.I. (2006). Kinetic studies on the absorption of cadmium, copper and zinc ions from aqueous solutions by cassava tuber bark waste. Bioresource Technology 97: 283-291.

Igbinosa, E. O. (2015). Effect of cassava mill effluent on biological activity of soil microbial community. Environmental Monitoring Assessment 187(418):1-9.

Igbinosa, E. O. and Igiehon, O. N. (2015). The impact of cassava effluent on the microbial and physiochemical characteristics on soil dynamics and structure. Jordan Journal of Biological Sciences 8(2):107-112.

Jena S.K. and Rath C.C. (2014). Effect of environmental and nutritional conditions on phosphatase activity of Aspergillus awamori. Current Research in Environmental and Applied Mycology. 4(1): 45 - 56.

Kadiri, D. D., Gorle, N., Peetala, K. V. R. and Peela, S. (2013). Isolation, screening and identification of phosphate solubilizing bacteria from different regions of Visakhapatnam and Araku valley. International Journal of Advanced Biotechnology and Research 4(4):518-526. 
Khan, M.S., Zaidi, A. and Ahmad, E. (2014). Mechanism of Phosphate Solubilization and Physiological Functions of Phosphate-Solubilizing Microorganisms. In In: Khan MS, Zaidi A, Musarrat J (eds): Phosphate Solubilizing Microorganisms. Springer International Publishing Switzerland pp 31-62.

Maharana, J.K. and Patel, A.K. (2013). Characterization of Physico-chemical Properties and their Impact on Enzyme Activities in a Chronosequence Coal Mine Overburden Spoil as Biomarker of Reclamation Process. Journal of Bacteriology and Parasitology 4: 174.

Mohamed, F. E., Toshinori, N., Jun, W. and Kenji, K. (2012). Isolation and characterization of cellulose-decomposing bacteria inhabiting sawdust and coffee residue composts. Microbes Environment 27(3):226-233.

Muniafu, M.M., Kahindi, J.H. and Kwena, M.O. (2015). Bio-ethanol production from cassava (Mannihot esculenta Crantz) at the coast region in Kenya. Research Journal Agriculture Environmental Management 4(7): 299 306.

Nautiyal, C. S., Bhadauria, S., Kumar, P., Lal, H., Mondal, R. and Verma, D. (2000). Stress induced phosphate solubilization in bacteria isolated from alkaline soils. FEMS Microbiology Letters 182:291-296.

Oboh, G., Akindahunsi, A.A. and Oshodi, A.A. (2002). Nutrient and antinutrient contents of Aspergillus niger fermented cassava products (flour and garri). Journal of Food Composition and Analysis 15: 617-622.

Okafor, J. O. (2008). Impact of effluents from garri processing industries on the environment in Bida, Niger state of Nigeria. Journal of Engineering and Applied Sciences 3 (6): 487-490.

Olorunfemi, D.I., Emoefe, E.O. and Okieimen, F.E. (2008). Effect of cassava processing effluent on seedling height, biomass and chlorophyll content of some cereals. Research Journal of Environmental Science 2: 221 - 227.

Oshoma, C.E., Igbeta, B. and Omonigho, S.E. (2017). Analysis of Microbiological and Physiochemical Properties of Top Soil from Municipal Dumpsites in Benin City. Journal of Applied Environmental Management 21(5): 985-990.

Oshoma C.E., Omorotionwan B.B. and Ebhohimen S.G. (2019). Improvement of Hydrocarbon degrading bacteria isolated from Automobile Mechanic Workshop Contaminated Soil using Rock Phosphate. Journal of Society for Experimental Biology of Nigeria, 19: 26 - 33

Oti, N. N. (2002). Discriminant functions for classifying erosion degraded lands at Otamiri, Southeastern Nigerian. Journal of Tropical Agriculture and Food Environment 3(1): 34-40.

Oviasogie, P. O., Ukpebor, E. E., Osharechiren, E. A. and Osayande, P. E. (2014). Fractionation of phosphorus in Soils amended with Sokoto Rock Phosphate, Cassava Mill Effluent and their effect on Maize (Zea Mays) growth. Nigerian Journal of Agriculture, Food and Environment. 10(3): 64-70.

Sagervanshi, A., Kumari, P., Nagee, A. and Kumar, A. (2012). Isolation and characterization of phosphate solublizing bacteria from Anand agriculture soil. International Journal of Life Science and Pharmacy Research 2(3):257266.

Sane, S. A. and Mehta, S. K. (2015). Isolation and evaluation of rock phosphate solubilizing fungi as potential biofertilizer. Journal of Fertilizers and Pesticides 6(2):1-6. 
Sharma, S. B., Sayyed, R. Z., Trivedi, M. H. and Gobi, T. A. (2013). Phosphate solubilizing microbes: sustainable approach for managing phosphorus deficiency in agricultural soils. Springer Plus 2:587-593

Utobo, E.B. and Tewari, L. (2015). Soil enzymes as bioindicators of Soil ecosystem status. Applied Ecology and Environmental Research 13(1): 147-169.

Vyas, T. K. and Dave, B. P. (2010). Effect of addition of nitrogen, phosphorus and potassium fertilizers on biodegradation of crude oil by marine bacteria. Indian Journal of Marine Sciences 39(1):143-150.

Watanabe, F. S. and Olsen, S. R. (1965). Test of an ascorbic method for determining phosphorus in water and $\mathrm{NaHCO}_{3}$ extracts from soil. Soil Science Society of America Proceedings 29:677-678. 